\title{
O JUIZ HERCÚLEO E A LETALIDADE DO ESTADO DOGMÁTICO
}

\author{
THE JUDGE HERCULES AND THE LETALITY OF THE \\ DOGMATIC STATE
}

Rosemiro Pereira Leal

PUC/MG

\begin{abstract}
Resumo
O mito do poder constituinte originário e os paradigmas de uma sociedade que se pretende fundada em um Estado de Direito são, nessa pesquisa, investigados em face de sua validade, eficácia e legitimidade.

Palavras-chave

Letalidade. Estado. Direito.
\end{abstract}

\section{Abstract}

The myth of the original constituent power and the paradigms of a society that is based on a Rule of Law are, in this research, investigated in the face of its validity, effectiveness and legitimacy.

Keywords

Lethality. State. Law

\section{INTRODUÇÃO}

Onde haja a incidência operacional de um direito que se rege por juízos epagógicos e pela proibição do non liquet uma bolha mágica (Estado Dogmático) emerge dessa contextualidade preceitual implantando a crença coletiva num ente fantasmal que a tudo e a todos envolve por uma

\footnotetext{
${ }^{1}$ Doutor em Direito Constitucional pela UFMG, professor da UFMG (Direito Processual e Econômico) e Especialista em Direito Público pela UFMG. Professor convidado de Direito Processual da Universidade Nova de Lisboa (UNL). Professor integrante da Popper Gallery da Universidade de Warwick (Inglaterra). Professor-co-fundador e implantador da pós-graduação stricto-sensu da Faculdade Mineira de Direito da PUC/Minas. Professor-fundador e implantador do Mestrado em Direito da Universidade FUMEC BH. Professor-fundador e implantador do Curso de Direito da Faculdade Arnaldo (BH). Fundador do Tribunal de Ética e Disciplina da OAB-MG. Ex-Conselheiro e Presidente da Comissão de Ensino Jurídico da OAB-MG, Membro Efetivo do Instituto dos Advogados de Minas Gerais. Presidente-Fundador da Associação dos Advogados de Minas Gerais e do Instituto Popperiano de Estudos Jurídicos (INPEJ).
} 
essencialidade noética (cimento místico) de agregação de pessoas (sociedade pressuposta) que adquirem unidade noemática (figurativa) expressa na voz hinária na qual se louva e exalta o sentimento patriótico (utópico) de paz e liberdade imorredouras, ainda que, para torná-las imortais, morram todos os seus ferrenhos defensores. Quando a utopia da paz e liberdade exige à sua sustentação o mito da JUSTIÇA, o fulcro de tal alucinação cultural arrima-se no epiquerema da escultura a delinear uma deusa (idola) com ou sem balança nas mãos, com ou sem venda nos olhos: os emblemas e tapumes são meros acessórios (escultura, imagem, quadro, pinturas) que criam a essência da unidade sígnica (noese) para a massa secularmente encarcerada nas redes de sentido da dominação carismática ou tradicional.

O que se pretende suscitar, em estreitas páginas, é a relação noéticonoemática na qual se forjam os paradigmas históricos de uma sociedade pressuposta (carcerária) com suas instituições arquetípicas sob o manto dos paradigmas históricos (metafóricos) de Estado Liberal, Social de Direito e similares: todos advindos do mito de um poder constituinte originário. Este que se perde na noite dos tempos, exercido por agentes eternamente capazes a manejarem a livre escolha de suas licitudes em forma permitida ou não proibida na lei de uma razão já universal para todos os homens, mas só revelável em sua plenitude na esfera instituinte da legalidade por uma jurisprudência dos interesses dominantes a estabelecer direitos iguais para iguais e desiguais para desiguais, tendo sua aplicação reservada à jurisprudência dos conceitos emanados das excelsas cortes de JUSTIÇA fundadas pela jurisprudência dos interesses instituídos e por sujeitos capacitados pela ilusão do escrutínio popular, universal e secreto.

É nesse marasmo mítico-utópico que se fará uma conjectura sobre a validade, eficácia e legitimidade, desse Estado de Direito cujos fundamentos se arrastam na obscuridade ao longo dos milênios em seus tentáculos entimemáticos.

\section{1- O CARÁTER LETAL DO ESTADO DOGMÁTICO}

Por vários artigos e obras, ao longo de estudos e pesquisas jurídicas, criei a expressão Estado Dogmático para designar a instituição protossignificativa de abrangência leviatânica (panótica) que, ao existir pelos ideais utópicos (essencialistas) de liberdade, paz, solidariedade, bem-estar 
social, primariamente intrínseca a uma sociedade historicamente pressuposta (mítica), gerencia-se por um sistema normativo criado e atuado pela lógica da Ciência Dogmática do Direito. É elementar que, para saber o que é essa Ciência, não é preciso, na atualidade, muito aprofundamento por leituras complexas e alentadas, exigindo-se apenas, no Brasil, correr os olhos nas obras de Tércio Sampaio Ferraz Júnior, Lourival Vilanova, Carlos Maximiliano, Miguel Reale, a não ser que o leitor queira mesmo percorrer atentamente a bibliografia utilizada por esses destacados juristas. Digo isso, porque o primeiro autor mencionado inaugura, dando prosseguimento ao percurso de Miguel Reale, o painel hermenêutico a ser adotado com a eclosão do regime autoritário de 1964, dotando o Judiciário de maiores convicções para a prática de um direito cuja eficácia se consolidasse na secular dogmática analítica que, a pretexto de socialização do direito, se expressa no voluntarismo da auctoritas e o segundo como difusor de uma hermenêutica desenvolvida pelo cognitivismo solipsista (cartesiano) a criar escopos metajurídicos que bem definem o autoritarismo hercúleo e sociologista do observador ordálico que já sabe em si o que é bom para todos. Ao se reger pela Ciência Dogmática do Direito, o Estado Dogmático funda-se e se exercita pelo alto saber psicologista dos sábios que, por mera piedade aos seus próprios professores, fingem que precisam do saber universitário (escolar) para ofertar ao mundo o esplendor de sua predestinada inteligência.

Para o sujeito (agente) kantianamente capaz por uma racionalidade já inata, o que o auxilia em sua jornada jurisprudencial (sentencial, decisional) é a apologia histórica abonada por um ensino de louvação a um sadio culturalismo (metafísica dos costumes). A pesquisa científica pela "Grande Ciência" não lhe apetece, tendo em vista que teria de colocar em conjecturas a ciência do dogmatismo que lhe confere a faculdade de zeteticamente doutrinar pelo senso comum e senso comum do conhecimento a exemplo do realismo crítico fregeano que inaugura a construção do saber por uma assembleia de experts insuscetível a juízos de falseabilidade na gênese de suas matrizes cognitivas que compõem as estruturas de revoluções científicas (Kuhn, Lyotard) de abertura de novos horizontes, sempre renovados e ampliados, de uma tecnologia que atende as seletivas necessidades dos povos sem que os problemas não pretendidos por 
essa celebrizada tecnologia sejam antes testificados quanto aos níveis de sofrimento humano e exclusão social que possam provocar.

A técnica, como atividade primal do homem ainda irracional, em forma de instrumentos artesanais de atenuação da hostilidade da natureza com utilização da própria natureza para moldá-la ao manejamento humano, foi, ao longo dos milênios, aperfeiçoada pela ciência (advento da racionalidade instrumental) para que o homem, retirando-se do lugar inóspito e infortunístico da rusticidade fabril (labor do faber primitivo), fundasse a atividade burocrática de não mais fazer os objetos operacionais de sua sobrevivência, mas de ensinar (atividade científica) fazer ( o fazer ordenado pela Ciência Dogmática) os objetos de tal sorte a criar duas classes: trabalhadores braçais e trabalhadores intelectuais, estes que não se importam com os danos (físicos, orgânicos, psíquicos) que a atividade laboral possa causar aos homens, atendo-se apenas aos resultados vantajosos que assumem o pomposo nome de riqueza das nações atualmente denominada PIB (Produto Interno Bruto de cada país). Esse PIB, dito criador de possibilidades de IDH (Índice de Desenvolvimento Humano), em sendo na perspectiva de Estado Dogmático, promove o humano numa relação custo-benefício e por ações afirmativas ${ }^{2}$. Nesse teor de compreensão, as teorias se confundem com as ideologias, contextualizando-se em conhecimento que, invés de significar "descobertas sobre a nossa ignorância", significam encobrimentos estratégicos de nosso secular obscurantismo sobre os fundamentos de qualidade de vida que configurasse dignidade mínima para todos e a se enunciar na possibilidade de auto ilustração sobre os conteúdos normativos do sistema jurídico praticado.

As estruturas lógicas do sistema jurídico do Estado Dogmático amparam a tese de que o Direito Positivo ${ }^{4}$ sic -:

\footnotetext{
${ }^{2}$ LEAL, Rosemiro Pereira. Isonomia Processual e Igualdade Fundamental a propósito das retóricas ações afirmativas, in Relativização Inconstitucional da Coisa Julgada, Editora Del Rey, BH, 2005, ps. $78 / 86$

3 POPPER, Karl. Conhecimento Objetivo: uma abordagem evolucionária, Tradução Milton Amado, BH, Editora Itatiaia, 1975

${ }^{4}$ VILANOVA, Lourival. As estruturas lógicas e o sistema do direito positivo, Editora Max Limonad, SP, 1997, p. 33
} 
".... visa a controlar a conduta, impondo formas normativas a essa conduta e, através delas, a alcançar fins, uns permanentes, outras variáveis, de acordo com o ritmo histórico e a índole própria das culturas (o gr. é nosso!)."

É oportuno frisar que a lógica jurídica para o autor mencionado, mestre da docência da construção positivista de Recife para São Paulo e deste para o Brasil do séc. XX, e "ramo da Lógica deôntica", Ciência do Direito, para o autor, envolve o "Direito como experiência" dos Tribunais, logo pelo "vínculo busserliano entre juíro e experiência ${ }^{5}$ É certo que esse autor e uma procissão de fiéis a esse positivismo jurídico-sociológico trabalham o sujeito inatamente cognoscente e todas as suas cogitações em lógica jurídica são destinadas à reafirmação do Estado Dogmático pelo psicologismo da auctoritas, consoante conjecturamos por vários artigos que contemplam a teoria neoinstitucionalista do processo $^{6}$. Nesse passo, o Direito, como discurso prescritivo, não se filia à lógica apofântica do verdadeiro e do falso, mas à deôntica do dever-ser. A proposição, como juízo lógico, é, para o positivista, em suas raízes eidéticas, certificada por um sujeito inatamente noético que se afigura como um "eu puro" que tem o condão na epoché de parentesear o mundo (Husserl), sem que os próprios lógicos "fenomenológicos" percebam que esse "eu puro" (epocal da epoché husserliana) é um nada essencial (entimemático) da linguagem metafórica como reflexo alucinatório (simulacro) do sujeito estruturalmente cognoscente que subjaz ao fundo de uma ilusória neutralidade (imparcialidade) a formar um conhecimento a priori como condição "científica" (determinativa de uma consciência superior de um saber dogmaticamente ordenado) antes mesmo dos condicionamentos egressos das com-participações sociais intersubjetivas.

O positivismo normativista de Kelsen, ao abraçar a fenomenologia husserliana, piora o seu quadro de ocultação estratégica da violência (letalidade) das formas materiais de vida já implantadas pela história do Estado Dogmático, porque continua a preponderar, nessa lógica formal de um

\footnotetext{
${ }^{5}$ VILANOVA, Lourival, Idem, p. 34

${ }^{6}$ LEAL, Rosemiro Pereira. A Teoria Neoinstitucionalista do Processo - uma trajetória conjectural, Arraes Editora, BH, 2013
} 
eu puro, o imparcialismo do saber apofântico da auctoritas cujas fontes não são suscetíveis de falseabilidade crítica, porque, a espelho de Dworkin ${ }^{7}$, ao quererem sair do positivismo jurídico, dizendo-se abandonar o pragmatismo e convencionalismo, sustentam uma integridade como condição de racionalidade, para a tutela jurisdicional, advinda de um significado entimemático (essencialista) para o Direito ao alcance exclusivo de um filósofo portador de um eu puro, a latere do mundo, capaz de uma única resposta correta como "decisão justa" alheia à legalidade estrita ${ }^{8}$. É certo que Dworkin, discípulo de Pound, precursor da Jurisprudência Sociológica norte-americana que trabalha precedentes como coleção de casos similares ou genuínos julgados pelos tribunais a instituírem coerência para as decisões, dá continuidade ao paradigma do Estado Social de Direito que é o eixo da autoridade pressupostamente lúcida, sábia, a operar as lógicas verificacionista e justificacionista a serviço de uma interpretação triunfal (trunfal). O juiz hercúleo assenta-se no trono do reinado das únicas decisões corretas (decisões justas) para retirar Hércules do monologismo do mito nomológico ao adotar uma moral objetiva que transcende às "morais individuais", reificando uma comunidade de fixos princípios preceituais para todos, ainda que as concepções sejam, de indivíduo para indivíduo, heterogêneas. Caberá ao juiz hercúleo (sacerdote de Hércules) interpretar (inter-parare), ou seja, suspendendo as ambiguidades semânticas dos sentidos normativos que tanto perturbam os positivistas, estabilizar, por um ponto fixo (eu puro) fora da legalidade estrita, uma consciência privilegiada de alta abstração a partir da qual conferisse integridade ao Direito, realizando (doando) uma irrestrita igualdade perante a lei para todos indistintamente.

O justificacionismo é uma lógica inerente à Ciência Dogmática do Direito que encontra sua pretensão de validade numa racionalidade talentosa, de fundo solipsista ou comunitarista, mas sempre inferida pelo voluntarismo da auctoritas a instalar o imperium de um direito jurisdicional de princípios e normas do tudo ou nada, onde o gênero principiológico torna as espécies normativas menores que a força do todo jurídico-sistêmico cuja integridade é inoculada pela lucidez imanente a um significante-mestre de

\footnotetext{
${ }^{7}$ DWORKIN, Ronald. O império do Direito, Martins Fontes, SP, 1999, ps. 5 e segs.

${ }^{8}$ TROPER, Michel. A filosofia do direito, Martins Fontes, SP, 2003, ps. 92-95
} 
um juiz hercúleo (julgador portentoso) só revelável, em sua essencialidade, aos seus próprios pares em iguais patamares de convicção (colegialidade de experts do realismo crítico fregeano) a sustentarem um núcleo duro de uma consciência judicante impermeável a argumentos que não lhe tenham a mesma escatologia. Por isso é que o sincretismo paradigmático de Estado Liberal e Social de Direito oscila no dogma analítico do indivíduocoletividade em que tais entidades essenciais (portadoras de direitos ontológicos), ao adquirirem forma jurídica (transparência) pelo discurso legal oriundo do mito do poder constituinte originário ${ }^{9}$ ou pela falácia do agorismo do escrutínio universal, implantam crenças pela utopização dos ideais de Justiça e Bem-Estar Social a serem ditos pela voz da jurisprudência dos conceitos como princípios que se consubstanciam dworkianamente em anseios comuns de uma comunidade humana como rede irrecusável de sentidos (pré-conceitos) que se enraíza na própria natureza do Direito a ser elucidado pela auctoritas (Gadamer, Apel, Habermas, Rorty, Dworkin).

É o enigma justificacionista (entimemático) da expressão natureza do direito é que torna o praxismo histórico de sua atuação pelo Estado Dogmático limites anônimos a serem decifrados pelo intérprete que busca ajustar (direito justo) a "natureza normativa" recebida da história (pragmático transcendental) às práticas sociais como se tais "práticas" significassem o que é melhor ou o que é de interesse de todos. Tais práticas não são perpassadas de fiscalidade processual, mas são tidas ideologicamente como condutas sobreviventes e vitoriosas no sangrento embate histórico das formas materiais de vida a serem jurisdicizadas pelo legislador ou por juízes hercúleos como garantidores de sentidos normativos já vigorantes antes mesmo de sua legiferação ou adaptadores clarividentes do direito recebido a novas realidades de sua portentosa escolha.

\section{2- O SIMULACRO DA INTEGRIDADE DO DIREITO}

\footnotetext{
${ }_{9}$ ARCANJO DOS SANTOS, Luiz Sérgio. Processo e Poder Constituinte Originário, Lumen Juris, RJ, 2016
} 
Os destinatários normativos são garimpeiros de sua própria equidade ao descobrir procedimentos para o exercício do poder político como influenciadores de decisões judiciais e governamentais protetoras de resultados moralmente justificável como ideia de Justiça, sendo que a integridade é um ideal de apelo patético da obediência governamental a princípios de justiça, equidade e devido processo legal, a estabelecer uma coerência como fonte de um Direito perene (principiológico) reconhecido ao longo de um tempo que não se explica se dogmático ou não dogmático analítico quanto ao grau de coercitividade (repressividade) à obtenção de finalidades não pré-decididas na base instituinte da própria normatividade implantada ou pela interdição de direitos já estratificada nas bases sociais de instituições políticas do passado inesclarecido. É esse romance macabro em cadeia, cujos capítulos históricos de guerras sucessivas (genocídios gloriosos) que marcam o Estado Dogmático, é que exige a presença do que há de pior nas guerras que é a secular sucessão da ditadura política pela tirania judicial ${ }^{10}$ : pior que a guerra declarada é a paz tirânica do Estado de Exceção ${ }^{11}$.

O "direito como integridade" em Dworkin é um esforço de romancistas jurisdicionais para escreverem capítulos de uma história gentilmente recebida do passado com acréscimos reconstrutivos e construtivos de artistas progressistas que medem suas habilidades pelo verificacionismo de uma pauta de valores (princípios) que resultem, a seus modos, em bem-estar social de uma comunidade histórica sempre in fieri (entregue a um tempo taumaturgo e a uma conciliação com suas próprias contradições que não são dadas a todos dilucidarem). Em Dworkin, princípios não se contrastam por teorias, mas se entificam em referentes míticos e imortais que balizam o senso comum e o senso comum do conhecimento. O seu método não é um teorométodo, mas uma narrativa cuja argumentação é tópico-retórica, porque não fornece os fundamentos epistemológicos que possam explicitar a extensão de sua visão de mundo: se monologista, dualista ou pluralista, limitando-se a raciocinar por metáforas e transformar o Direito num romance histórico linear a adquirir

\footnotetext{
${ }^{10}$ CARRIÓ, Genaro R. Sobre los límites del lenguaje normativo, Buenos Aires: Astrea, 1973

${ }^{11}$ AGAMBEN, Georgio. Estado de Exceşão. Tradução Iraci D. Poleti, SP: Boitempo, 2004
} 
sentido (integridade) pelo poder jurisprudencial das decisões judiciais. A escolha entre princípios é abdutiva, até mesmo a reductio ad-absurdum é ao juiz ofertada se só o absurdo lhe parecer criativo de uma racionalidade reflexa de uma realidade já historicamente implantada e absorvida por uma comunidade de pessoas unidas por laços sociais consistentes.

Entre seus reificados princípios não há vencedores ou vencidos definitivamente, a qualquer momento um princípio adormecido poderá, de inopino, emergir do cérebro fecundo da auctoritas e surpreender a todos como sinal de criatividade luminosa e singularidade invejável a tornar o direito previsível no instante decisório de sua prolação. Esse direito assim nascido incide sobre uma realidade em bases protocolares encontradas pelo homem em seu sangrento percurso histórico. À medida que essa realidade impregnada de princípios imortais, mergulhada na milenar dogmática analítica (desde Aristóteles só para exemplificar), não é pesquisada criticamente em seus juízos de existência e consciência, o que se depreende é uma armadilha (gaiola) de tipos puros de dominação ${ }^{12}$ vestidos pelo simulacro da boa-fé do intérprete-juiz ${ }^{13}$ que é a prótese que oculta a má-fé irrevelada de seu vantajoso obscurantismo amparado pelo atributo do despotismo de sua vontade nua (em vão) ininterrogável ante o temor geral das populações amedrontadas que a qualquer momento podem ser surpreendidas pela ressurreição de um princípio que, ao conflitar com outros, passa a ter a preferência majestosa do juiz. Vê-se ainda no discurso (decurso histórico) que o "devido processo legal" é um adjetivo do "conceito" ordálico de Justiça, devendo prevalecer, em caso de conflito entre ambos, o "melhor possível do ponto de vista da moral política", o que bem define o caráter histérico (psicologista) de tal escolha.

Em Dworkin, é bem mais visível a advertência de Barnes ${ }^{14}$ de que "o silogismo Aristotélico" nos domina há séculos e, ao afirmar que o Direito não pode ser descrito, mas somente interpretado, preconiza um direito já

\footnotetext{
12 WEBER, Max. Três tipos puros de dominação legítima, in, FERNANDES, Florestan (Coord.); COHN, Gabriel (Org.). Max Weber: Sociologia. Tradução Amelia Cohn e Gabriel Cohn, 4ª ed., SP, Ática, 1989 (série Grandes cientístas sociais, v. 13) 13 SÁ BATISTA, Sílvio de. Má-fé e Boa Fé na Processualidade Democrática, Lumen Juris, RJ, 2015

${ }^{14}$ BARNES, Jonathan. Aristóteles, Ediciones Cátedra, Madrid, 1982, ps. 143 e segs.
} 
autopoiético desde sempre para a humanidade, a sofrer transformações normativas, nunca principiológicas (categoricamente imperativos e vigorantes para as comunidades) de tal sorte a criar uma imutabilidade e estacionar o sentido para o intérprete que jamais poderá transcrevê-lo, mas dizer o que há nele de bom, de útil, de coerente, para todos. Essa pretensão objetivista de um direito que traz em si a sua própria compreensão poderia até mesmo dispensar a sua interpretação, porque esta significaria a mera aplicação pela auctoritas como achador de seus melhores e luzidios significados.

\section{3- PROCESSUALIDADE VERSUS INTEGRIDADE}

Enquanto a integridade dworkiana é significada por uma coerência de princípios, logo por uma demarcação dogmática que se apoia no mito baconiano da epagoge a exigir intérpretes inatamente lúcidos e imanentes à realidade social e política, a processualidade é uma teoria jurídica que se desenvolve por proposições indicativas de uma ordem progressiva de atos jurídicos sequenciais a se constituírem em estrutura técnica advinda de modelos adredemente criados em lei compositivos do devido processo legal, embora o CPC/2015, em flagrante retrocesso, ao espelho de JHERING, adotando perspectivas do realismo mecanicista do empirismo lógico do Estado Dogmático, permitiu a flexibilização procedimental pela esdrúxula "cooperação" (convenção) mútua de juiz e partes (arts. 190, 191 e 357). Está-se vendo que o NCPC sofre, por vários trechos, perda insanável de democraticidade discursiva pela síndrome sociologista poundiana de um escuso "processo jurisdicional" em que a jurisdição indutiva do decisor sobrepõese transcendentalmente ao processo ainda que considerado apenas na concepção fazzalariana. A ideologia do Direito como integridade reifica uma comunidade de princípios congênitos (fatores de coerência) a uma comunidade política captáveis por mentes privilegiadas (empirismo lógico) como que a gerar uma jurisdicidade e antijurisdicidade de conceitos (subjacentes) à existência em si de uma comunidade historicamente encontrada pelo intérprete como tradutor de sua linguagem isotópica e extralinguística à espera de dilucidação hercúlea à formação de uma só resposta correta ante a complexidade dos conflitos jurídicos. 
Há sempre, em Dworkin, uma sociedade pressuposta já comungando princípios como cimento místico de uma união de todos sensibilizáveis pelos decisores como crentes holísticos em valores sociais imutáveis em sua essencialidade universal de fundo aristotélico-escolástico. Em Dworkin, portanto, acolhe-se que o Direito é bem maior e mais importante que a lei, porque aquele abrange princípios implícitos na própria legalidade que é um sistema lacunoso a ser preenchido pelo aplicador do Direito pela negação radical do non-liquet. O devido processo legal nessa conjuntura de preservação de uma comunidade política como comunidade entelequial de princípios que se historizam por sucessão secular de seus romancistas em cadeia (decisores clarividentes), a que o Estado deve prestar obediência, é mero "adjetivo" dos princípios epagógicos de justiça e equidade já ínsitos na prática (praxis) jurídica de uma comunidade a ser preservada ou reconstruída paulatinamente pelos aplicadores do Direito (auctoritas).

Nesse diapasão, dworkianos gozam de uma liberdade pendular de estar ao mesmo tempo dentro e fora da lei ${ }^{15}$, mas guardando sempre uma imanência com princípios autorreguláveis a emprestar coerência estrutural à comunidade política. O Direito, nesse passo, não é juridificante, mas sempre jurisdicizante de uma realidade sócio-política historicamente encontrada e interpretada em seus capítulos (fases históricas) a exigir coerência de novos intérpretes que se sucedem ao longo dos tempos com especial perspicácia reconstrutiva para melhorar seus escopos metajurídicos que os juízes hercúleos podem engendrar para todos pela via de decisões que harmonizam a jurisprudência dos interesses legislados e a jurisprudência dos conceitos magnos a serem postos por uma sensitiva atividade jurisdicional. Fica claro que o Direito a ser manejado em juízos de justiça e equidade (entidades míticas por significantes não significados) somente são suscetíveis de estabilidade de sentido normativo pelo poder da auctoritas não ensejando uma bermenêutica isomênica ${ }^{16}$ por não lhe ser relevante a atuação de fiscalidade processual desde o nível instituinte da legalidade.

15 CARRIÓ, Genaro. ob cit.

${ }^{16}$ LEAL, Rosemiro Pereira. Teoria Processual da Decisão Jurídica, D'Plácido Editora, BH, $2^{\mathrm{a}}$ ed., 2016 
Ao pretender uma interpretação induzida de uma realidade sóciopolítica encontrada historicamente, aceita-se o suplício geral por um Direito orgânico aplicável por doutrinadores que, ao ficarem entre a zetética e a dogmática analítica, imunizam os seus saberes de tal sorte a sustentar uma comparticipação de todos numa comunidade política, cujos fundamentos de sua implantação histórica são capítulos de um passado insuscetível à crítica de sua própria racionalidade já considerada intrínseca a um sistema principiológico de sua sobrevivência e perene como um romance desastrado que não se sabe onde começou nem onde termina. O intérprete fica boiando em seu fluxo por uma lógica compreensiva só acessível à inteligência de decisores já pertencentes a uma sociedade pressuposta17 antes mesmo de galgar o título de juízes por uma investidura solene nas funções só destinadas a mentes hercúleas que possam suportar a pesada carga de repressividade dos sistemas anacrônicos de Estados liberal e social de Direito por uma violência de uma vontade que assume o poder mágico de julgar muito além da soberana crueldade do Estado Dogmático ${ }^{18}$ que envolve a comunidade político-principiológica como uma bolha imantada de uma unidade já posta por uma história taumaturga (Hegel).

O direito, ao se tornar integridade por princípios imutáveis e infungíveis, sempre balizando uma só resposta correta para cada caso em exame pela autoridade jurisdicional que os recolhe e escolhe na subjacência de uma história social já cristalizada, tida como única possível, exigiria de uma inteligência a realizar tal proeza a máxima radicalização do indutivismo. David Hume, que elegeu o empirismo lógico pela força do hábito (ocorrência prolongada de regularidades dos fenômenos humanos ou naturais geradores de expectativas de certeza), entendia que tal critério agravava ainda mais o seu ceticismo quanto à possibilidade de uma lógica fornecedora de "respostas corretas" para os problemas, a não ser que os observadores se louvassem em crenças, renunciando às falsas pretensões científicas de verdade-validade (integridade).

${ }^{17}$ LEAL, Rosemiro Pereira. Processo como Teoria da Lei Democrática, Editora Fórum, BH, 2017, $2^{a}$ ed., p. 40

${ }^{18}$ LEAL,Rosemiro Pereira. A Teoria Neoinstitucionalista do Processo - uma trajetória conjectural, Arraes Editores, BH, 2013 
Aliás, o debate sobre o empirismo lógico assumiu especial relevo nas Escolas de Viena e Frankfurt, porque ambas as escolas referidas, por vertentes diferenciadas, estavam mergulhadas no positivismo, com exceção de Adorno e Benjamim ( $1^{a}$ geração da Escola de Frankfurt) que, apesar das objeções posteriores de Habermas, não acolhiam o totalitarismo de uma única racionalidade para avaliação de um sistema historicamente dialético de tal sorte que a sintese vitoriosa pelas guerras pudesse impor princípios a se perenizar como verdades absolutas. É que Adorno, diferentemente de Habermas (seu ex-aluno), preconizava uma dialética negativa, não pelo exclusivo apontamento de aporias em face de uma dialética histórica positiva (positivista, vigorante, implantada por uma razão instrumental conforme fins, pouco importando os meios), mas pelo que sobrava desse sistema totalizante e estratégico a configurar um não-idêntico como anti-sistema de onde uma racionalidade crítica (continuadamente antitética) pudesse excursionar e frustrar as expectativas da visão totalitária do EstadoNacional, padronizado em seus símbolos e princípios cívicos por uma integridade ideológica como referente corretivo de suas disfunções (conflitos de interesses).

Também é misterioso o plano de existência de princípios que sustentam o direito como integridade porque apresentam, em seus conteúdos, uma volubilidade só pacificável pelo senso de lucidez de um decisor hercúleo. Vale-se o decisor de um senso-comum de alto calibre e de uma pontaria de uma precisão hermenêutica invulgar para desatar (resolver) hard cases, porque, para os adeptos de tal esquematismo à preservação, ora da comunidade de princípios que associam indivíduos, ora de princípios que embasam a conduta do Estado, o talento e a sensibilidade do decisor oscilam entre a intuição kantiana, a dialética idealista de Hegel e a sociological jurisprudence de Roscoe Pound pela análise atenta de casos precedentes. Depreende-se da trama do julgamento com base no direito como integridade que a auctoritas decisora reina em parâmetros que vão da transcendentalidade mais inefável ao materialismo histórico da formação das comunidades jurídico-políticas de grande e intrincada complexidade. As partes, como sujeitos do processo judicial, nessas circunstâncias, são para o decisor, integrantes prima facie de uma sociedade política ex-ante de seu ingresso em juízo, podendo o caso trazido a juízo ser julgado por princípios não 
jurisdicizados, sendo irrelevante, em muitas hipóteses, a legalidade estrita à solução da controvérsia ${ }^{19}$. O devido processo legal dispensa prévios modelos estruturais da ordinariedade plena ou sumária (fundamentos da cognitio) para assegurar contraditório ou ampla defesa, uma vez que tais direitos são, no direito como integridade, assegurados pelo juiz como tutela que a autoridade confere às partes, dosando-lhes a conveniência cuja amplitude é posta por seus juízos de equidade (decisão justa). Aliás, Galuppo ${ }^{20}$ assim se pronunciou quanto à integridade dworkiana: -sic-

\footnotetext{
"Uma decisão é justa (ou seja, respeita a Integridade do direito) se fornece a resposta correta (mesmo que esta não se baseie na estreita legalidade) para o caso".
}

O direito como Integridade é o corolário hermenêutico do paradigma do autoritário Estado Social de Direito que se alimenta da liberal Ciência Dogmática do Direito para engrossar as fileiras de doutrinadores que se servem de ideologias de cunho positivista (epagógico) com a utilização de rótulos teóricos que de teoria nada apresentam na perspectiva do racionalismo crítico popperiano que sempre foi uma trincheira permanente contra o positivismo (o milenar empirismo lógico da epagoge grega). Popper lamentou que Habermas o rotulara de "positivista" a propósito de seu debate com Adorno. É que Habermas, apegando-se à sua "trivial21" teoria do agir comunicativo que deposita na intersubjetividade o seu pleito de saída da filosofia da consciência, foi inadvertidamente colhido pelo "mito do contexto22" da pragmática transcendental de Apel, conferindo à esfera pública o atributo autopoiético de entendimento humano advindo de uma rede positivista

\footnotetext{
19 TROPER, Michel. Ob. cit, ps. 92-95

${ }^{20}$ GALUPPO, Marcelo. Igualdade e Diferença: Estado Democrático de Direito a partir do pensamento de Habermas, Editora Mandamentos, BH, 2002, p. 285

${ }^{21}$ POPPER, Karl. A Lógica da s Ciências Sociais, Tradução de Estevão de Rezende Martins, et al. Brasília: Universidade de Brasília, 1978

22 POPPER, Karl. O Mito do Contexto, Edições 70, Lisboa, 1996
} 
(real social como racional) de validade de falas históricas de sentido irrenunciável para todos. Popper ${ }^{23}$ assim se expressou: - sic-

\begin{abstract}
"O fato de que o rótulo "positivismo" me tenha sido aposto a priori por um erro grosseiro pode ser verificado por qualquer um que esteja em condições de ler a minha Lógica do Conbecimento Científico"
\end{abstract}

Esse achar princípios na realidade social ou natural que recomendam saberes adstritos ao realismo crítico aos moldes kuhnianos, poundianos (dos quais Dworkin é inegável seguidor), tem raízes nas teses fregeanas da filosofia da Escola Analítica anglo-germânica, não guardando, em seu positivismo lógico, qualquer aderência ao racionalismo crítico que afirma a irracionalidade de se ter a razão em si como reguladora de racionalidade. No entanto, o que é relevante para conjecturar uma coinstitucionalização democrática (não paideica) de um Direito na contemporaneidade é a identificação de procedimentos processualizados no bojo de um sistema normativo vincado, desde sempre, por uma teoria processual a ensejar uma fiscalidade pelo devido processo desde o nível instituinte ao nível coinstituído da normatividade jurídica. O constitucionalismo, nessa perspectiva neoinstitucionalista, perde o elo com a dialética do materialismo histórico que determina (cria) um ser social para o homem de tal modo a fecundar uma escatologia principiológica insuscetível à rejeição e, ao ser detectada por mentes hercúleas, guarde características de um cimento místico que orienta, por consensos havidos nos corredores isotópicos de uma sociedade ou Estado-Nação, decisões corretas para cada caso per si.

Segundo descreve Atienza ${ }^{24}$, "a crítica de Dworkin a Hart, como a entende Mac Cormick, se concentra em quatro pontos" que não passam pela cogitação do instituto do "devido processo legal, sequer Mac Cormick, ao rejeitar a noção de princípio utilizada por Dworkin", cuida dos direitos fundantes da processualidade linguístico-jurídico-autocrítica, para

\footnotetext{
23 POPPER, Karl. A Lógica das Ciências Sociais, Biblioteca Tempo Universitário, no 50, 1978 , p. 47

${ }^{24}$ ATIENZA, Manuel. As Raz̃ões do Direito, Editora Landy, SP, 2000, ps. 196-200
} 
fazer seus reparos ao realismo hermenêutico dworkiano. É certo que Dworkin trabalha o velho paradigma de Estado-Nação como uma esfera dogmática idêntica a si mesma ${ }^{25}$ por princípios solidificados num modelo social (sociedade pressuposta) que lhe dá substrato e sustentação: o achador (racionalizador) desses princípios é o privilegiado esclarecedor dialético, é o detentor de uma visão holística de uma totalidade social vitoriosa, repressiva, de fundamentos historicamente pré-conceituados, já interpretados, a serem escolhidos pela auctoritas para proferir decisões fortalecedoras da reprodução do sistema.

Nesse nebuloso horizonte, o Estado Democrático é mero rótulo (marca) ${ }^{26}$ acrescido ao Estado Social de Direito que recebe, após enxertado pela retórica da democracia liberal-comunitarista, o selo de qualidade de um especial "Estado Social Democrático de Direito" a significar um sofisticado "tipo puro de dominação legítima" pelo sincretismo despótico de uma aliança estratégica entre o carisma de seus líderes, a lúcida inteligência de seus doutrinadores e a burocracia mecanicista de seus fiéis servidores ${ }^{27}$. A interpretação dworkiana para alcançar integridade pela única resposta correta aos hard cases exige do intérprete uma genial flexibilidade perceptiva que, ao abandonar ou assimilar aspectos do convencionalismo e do pragmatismo, não se comprometa demasiadamente com o passado e obtenha exata compreensão das práticas sociais presentes, porque há de contemplar um direito em mutação, optando pelos valores integrantes de um ideal de justiça e equidade, inerentes a uma população, só reveladas a um juiz clarividente.

O debate em se saber se Dworkin distingue ou não Direito e Moral pelas opiniões de Ikawa, Mans e Alexy (que entendem não haver distinção para Dworkin) ao lado da afirmação em contrário de Habermas e Günther, é estéril para situar um direito de Estado não-Dogmático, porque,

\footnotetext{
${ }^{25}$ SUBIRATS, Eduardo. Dialética do Esclarecimento: um olhar retrospectivo, in Theoria Aestética, em comemoração ao centenário de Theodor W Adorno, Escritos Editora, Porto Alegre, 2005, ps. $155-165$

26 BROWN, Wendy. Democracia em Suspenso, Ediciones Casus Belli, 2010, ps. 59 e segs. ${ }^{27}$ WEBER, Max. Três tipos puros de dominação legítima, in FERNANDES, Florestan, Editora Ática, $4^{a}$ ed., SP, 1989
} 
ao final de contas, esse direito será mero instrumento da Jurisdição para o juiz externar, com sua caleidoscópica vontade, a vontade concreta de uma sociedade, compativelmente, ou não, com as leis adotadas. É óbvio que quem trabalha com princípios morais e políticos na base de sistemas jurídicos arrisca-se em suas reflexões mais profundas sobre conflitos (casos) daí emergentes a entender que há na subjacência das legislações uma imanência de sociedade política e bem comum ou uma ressonância magnética do pacto rousseauniano firmado em algum momento da história dos homens em que a fala se tornou inerente ao entendimento só audível pela escuta sutil da autoridade jurisdicional. É uma versão arrojada do mito do contexto que é o padroeiro das teses da ação comunicativa de Habermas-Apel por uma pragmática transcendental universal. Nesses parâmetros, porque Dworkin oculta o segredo da escuta histórico-políticojurídica de seu juiz Hércules, jamais se sabe ao certo a fonte da Justiça, Equidade e do Devido Processo Legal em Dworkin: se no positivismo jurídico ou sociológico, se na jurisprudência mecânica ou na sociológica de Roscoe Pound. Dworkin não trabalha direitos pré-cógnitos (fundamentais autoaplicáveis), sequer cogita de uma teoria da lei28 gestora desses direitos. Se princípio em Dworkin, podendo ser ou não ser norma jurídica legislada e, em sendo um consectário de justiça e equidade que, a seu turno, são juízos noéticos (entimemáticos) de conotação essencializante sem forma (unidade) como a ideia de uma corrente aérea, de uma onda, de um "isso", de "algo", fica claro que Dworkin acolhe a proibição do non-liquet como devoto do juízo da "razão suficiente" da jurisdictio.

Enfim, ao se buscar uma única resposta correta para hard cases no leito de uma comunidade histórica de sentidos epiqueremáticos (o comumente admitido), exclui-se a comunidade de legitimados ao devido processo legal que se valem de uma teoria de uma técnica processual não entregue à mente construtiva-reconstrutiva de um suposto e prodigioso decisor. $\mathrm{O}$ que se vê que a ambição interpretativa de Dworkin vai muito além das lógicas apofântica e deôntica de Aristóteles por um princípio hegeliano de um terceiro incluído (ser-e-não-ser) a sinalizar um devir só 
previsível pela atividade jurisdicional de cortes excelsas ${ }^{29}$. Ao se louvar em precedentes tribunalícios para lavrar uma única resposta correta, Dworkin apega-se à lógica verificacionista-justificacionista que é própria da autoridade, não cogitando, sequer em Fazzalari, de um direito fundamental ao devido processo para, por uma teoria da técnica procedimental, estabelecer uma ordinariedade modelar de atos jurídicos a disciplinar (demarcar) a atuação dos sujeitos do processo na preparação das decisões.

No entanto, como se depreende, Dworkin está mais interessado em escrever um romance no qual cada capítulo, como decisão judicial, estabeleça um elo de coerência com os que lhe antecedem do que aferir os conteúdos jurídicos de argumentação das partes que possam barrar coerências de uma linguagem pretoriana divorciada da simétrica paridade entre partes e juiz na preparação de uma decisão que irá afetar um ou alguns dos demandantes, uma vez que, para Dworkin, só o decisor jurisdicional é que teria, no saber de sua velada solidão, a exata dimensão da essencialidade dos juízos de justiça e equidade 30 jamais disponíveis a mentes não autorizadas pelo PODER judicante ou pelo prestígio doutrinário à consolidação do dogmatismo tópico-retórico que caracteriza o paradigma de Estado do bem-estar social que é dworkiano.

Com a obra "Teoria Processual da Decisão Jurídica ${ }^{31 "}$ (já na sua terceira edição) dei resposta a todos aqueles que, como os norteamericanos Roscoe Pound e Dworkin, ao abandonarem o mecanicismo decisionista de procedência britânica e adotarem o sociologismo jurisprudencialista de índole Norte-Americana, nada inovaram para uma pós-moderna concepção de Estado Democrático de Direito em paradigma já recepcionado pela coinstitucionalização processual do Direito no Brasil de 1988, tendo em vista que, em ambas as correntes (inglesa e americana), prevalece a regra autocrática da proibição do non-liquet e do império da jurisdictio por uma "justiça judiciária" que associa a lei ao saber

\footnotetext{
${ }^{29}$ DWORKIN, Ronald. Levando os Direitos a Sério, Martins Fontes, SP, 2002, ps. $46-47$ e 173

30 DWORKIN. Ronald. Império do Direito, Martins Fontes, SP, 2003, ps. 288-294

${ }^{31}$ LEAL, Rosemiro Pereira. Teoria Processual da Decisão Jurídica, D'Plácido Editora, $3^{\mathrm{a}} \mathrm{ed}$., BH, 2017, BH
} 
decisório dos juízes ${ }^{32}$. Aliás, o NCPC/2015, forte em tutelas interditais de direitos fundamentais do processo já coinstitucionalizados no Brasil em 1988, é herdeiro do velho modelo social do processo egresso das teses de Arton Menger e Franz Klein (modernamente Picardi) que são os pioneiros de uma justiça judiciária em paradigma de Estado Social (que era a Ordenança Processual do Império Austro-Húngaro de seu tempo (1895), sem que se cogitasse de uma teoria da lei como se impõe pela teoria neoinstitucionalista do processo ao balizamento paradigmático de Estado Democrático de Direito na contemporaneidade (pós-modernidade).

\section{REFERENCIAS}

AGAMBEN, Georgio. Estado de Excȩão. Tradução Iraci D. Poleti, SP: Boitempo, 2004

ARCANJO DOS SANTOS, Luiz Sérgio. Processo e Poder Constituinte Originário, Lumen Juris, RJ, 2016

ATIENZA, Manuel. As Razões do Direito, Editora Landy, SP, 2000, ps. 196200

BARNES, Jonathan. Aristóteles, Ediciones Cátedra, Madrid, 1982, ps. 143 e segs.

BROWN, Wendy. Democracia em Suspenso, Ediciones Casus Belli, 2010, ps. 59 e segs.

CARRIÓ, Genaro R. Sobre los límites del lenguaje normativo, Buenos Aires: Astrea, 1973

DWORKIN, Ronald. Levando os Direitos a Sério, Martins Fontes, SP, 2002, ps. 46-47 e 173

32 POUND, Roscoe. Justiça conforme a Lei, IBRASA,SP, no 30, ANO 1965, p. 93 
. O império do Direito, Martins Fontes, SP, 1999, ps. 5 e segs.

294

. O Império do Direito, Martins Fontes, SP, 2003, ps. 288-

GALUPPO, Marcelo. Igualdade e Diferença: Estado Democrático de Direito a partir do pensamento de Habermas, Editora Mandamentos, BH, 2002, p. 285

LEAL, Rosemiro Pereira. A Teoria Neoinstitucionalista do Processo - uma trajetória conjectural, Arraes Editora, BH, 2013

- Isonomia Processual e Igualdade Fundamental a propósito das retóricas ações afirmativas, in Relativização Inconstitucional da Coisa Julgada, Editora Del Rey, BH, 2005, ps. 78/86

- Processo como Teoria da Lei Democrática, Editora

Fórum, BH, 2017, $2^{\mathrm{a}}$ ed., p. 40

Editora, BH, $3^{\mathrm{a}}$ ed., 2017

- Teoria Processual da Decisão Jurídica, D'Plácido - A Teoria Neoinstitucionalista do Processo - uma trajetória conjectural, Arraes Editores, BH, 2013

POPPER, Karl. Conhecimento Objetivo: uma abordagem evolucionária, Tradução Milton Amado, BH, Editora Itatiaia, 1975

50,1978 , p. 47

. Lógica das Ciências Sociais, Biblioteca Tempo Universitário, $\mathrm{n}^{\circ}$ . O Mito do Contexto, Edições 70, Lisboa, 1996

POUND, Roscoe. Justiça conforme a Lei, IBRASA,SP, n 30, p. 93 
SÁ BATISTA, Sílvio de. Má-fé e Boa Fé na Processualidade Democrática, Lumen Juris, RJ, 2015

SUBIRATS, Eduardo. Dialética do Esclarecimento: um olhar retrospectivo, in Theoria Aestética, em comemoração ao centenário de Theodor W Adorno, Escritos Editora, Porto Alegre, 2005, ps. 155-165

TROPER, Michel. A filosofia do direito, Martins Fontes, SP, 2003, ps. 92-95

VILANOVA, Lourival. As estruturas lógicas e o sistema do direito positivo, Editora Max Limonad, SP, 1997, p. 33

WEBER, Max. Três tipos puros de dominação legitima, in, FERNANDES, Florestan (Coord.); COHN, Gabriel (Org.). Max Weber: Sociologia. Tradução Amelia Cohn e Gabriel Cohn, 4ª ed., SP, Ática, 1989 (série Grandes cientístas sociais, v. 13) 